\title{
Genetic and environmental effects on early growth and performance in purebred Holstein, Jersey, and reciprocal crossbred calves
}

\author{
J. V. Ware,${ }^{* 1}$ S. T. Franklin, ${ }^{* 2}$ J. Jackson,,${ }^{*}$ A. J. McAllister, ${ }^{* 4}$ and B. G. Cassell† \\ ${ }^{*}$ Department of Animal and Food Sciences, University of Kentucky, Lexington 40506 \\ †Department of Dairy Science, Virginia Polytechnic and State University, Blacksburg 24061
}

\begin{abstract}
For this designed experiment, Holstein $\times$ Holstein $(\mathrm{n}=28)$, Jersey $\times$ Jersey $(\mathrm{n}=10)$, Holstein $\times$ Jersey $(\mathrm{n}=15)$, and Jersey $\times$ Holstein $(\mathrm{n}=15)$ bull and heifer calves were compared for body weight $(\mathrm{BW})$, dry matter intake, feed efficiency, hip height, BW gain to 42 and $56 \mathrm{~d}$, and days to weaning from birth to 8 wk. All traits were examined for purebred, maternal, and heterotic genetic effects. Purebred genetic effects significantly favored the Holstein breed for BW, dry matter intake, hip height, and BW gain to 42 and 56 d. Heterotic genetic effects were present for dry matter intake and hip height. Calf sex affected BW and BW gain to $56 \mathrm{~d}$. Our results indicate that early calf growth is influenced primarily by purebred effects favoring the Holstein breed and to a lesser extent heterosis.
\end{abstract}

Key words: crossbreeding, dairy calf, growth

\section{INTRODUCTION}

Crossbreeding in the commercial dairy industry is gaining popularity as producers try to maximize longevity, health, and economic efficiency of cows in their herds (Weigel and Barlass, 2003). Improved understanding of growth and performance of crossbred dairy calves may help producers use crossbreds more efficiently in commercial dairy systems. The economic benefits of using crossbreds in dairy systems are well documented (Touchberry, 1992; McAllister et al., 1994; Lesmeister et al., 2000; Lopez-Villalobos et al., 2000; Sørensen et al., 2008; Buckley et al., 2014), as are growth and performance traits for pureline and crossline animals (Batra and Touchberry, 1974; McDowell, 1982; Lee et al., 1988; Heins et al., 2008; Olson et al., 2009). A potential economic benefit of crossbreeding is earlier weaning

Received February 14, 2014.

Accepted October 8, 2014.

${ }^{1}$ Current address: Department of Integrative Physiology and Neuroscience, Washington State University, Pullman 99164-7620.

${ }^{2}$ Current address: PO Box 38, Magnolia, KY 42757.

${ }^{3}$ Deceased.

${ }^{4}$ Corresponding author: amcallis@uky.edu because it allows producers to decrease labor costs and may aid in lowering feed costs (Davis and Drackley, 1998; Kehoe et al., 2007). Growth rates influence time of weaning, age at first calving (Heinrichs and Swartz, 1990; Cady and Smith, 1996), and subsequent milk production (Virtala et al., 1996). Whereas many of these studies focused on growth and performance traits for calves 3 mo of age and older, little is known about the very early growth and performance of purebred calves compared with crossbred calves. The objectives of this designed experiment were to compare growth and performance traits of purebred Jersey and Holstein calves with Holstein $\times$ Jersey and Jersey $\times$ Holstein $\mathrm{F}_{1}$ crossbred calves from birth to 8 wk and estimate the purebred, maternal, and heterotic genetic effects on those traits.

\section{MATERIALS AND METHODS}

\section{Animals}

From January 2003 to January 2004, purebred Holstein and Jersey nulliparous heifers and primiparous and multiparous cows from the University of Kentucky research dairy herd were inseminated using heterospermic semen (Select Sires Inc., Plain City, $\mathrm{OH}$ ) as part of a large, multiherd designed experiment (Olson et al., 2009). Straw composition was $50 \%$ Holstein semen and $50 \%$ Jersey semen from 4 Holstein and 4 Jersey bulls (Table 1), allowing for equal opportunity of fertilization (Kasimanickam et al., 2006). Holstein and Jersey bulls were chosen with the following criteria: (a) they were alive and producing semen; (b) the 4 sires chosen from each breed were in the top $50 \%$ of active AI sires for net merit at the time of selection in 2001, endeavoring to choose one bull each from the 90th, 80th, 70th, and 60 th rank percentiles; and (c) the bulls chosen should be as unrelated to each other as was possible so that inbreeding in the pure genetic lines would not favor either breed. Matings were made to avoid close relationships between the purebred bulls and the purebred Holstein and Jersey cows to which they were mated. Females were randomly assigned to be inseminated with 1 of 
the 16 heterospermic combinations, except for avoidance of significant inbreeding of potential offspring. Approximately 1 wk before expected parturition, or as indicated by a drop in serum protein concentration and visual appraisal, a Foal Alert system (Foalert Inc., Acworth, GA) transmitter was attached to the vulva of each cow. The Foal Alert system notified researchers of the imminent birth of a calf. From November 2003 to December 2004, 68 bull and heifer calves born to cows inseminated using heterospermic semen were used with genetic groups representing purebred Holstein $(\mathrm{n}=28$, representing all 4 Holstein sires), Holstein $\times$ Jersey $(\mathrm{n}=15$, representing all 4 Holstein sires), Jersey $\times$ Holstein $(\mathrm{n}=15$, representing all 4 Jersey sires), and purebred Jersey ( $\mathrm{n}=10$, representing 3 Jersey sires). The number of progeny by sire (Table 1 ) showed that all 4 Holstein sires had progeny in both the purebred Holstein and Holstein $\times$ Jersey groups and all 4 Jersey sires had progeny in the Jersey $\times$ Holstein group. Three Jersey sires had progeny in the purebred Jersey group. Only one Jersey sire had a single progeny, that being in the Jersey $\times$ Holstein group.

All experimental procedures followed University of Kentucky Institutional Animal Care and Use Committee guidelines. Newborn calves were removed from their dam immediately after birth to prevent maternal suckling and were weighed. To determine amount of colostrum needed, BW was recorded and rounded to the nearest $4.5 \mathrm{~kg}$ increment. Colostrum was fed at $5 \%$ of rounded BW within $3 \mathrm{~h}$ of birth. The colostrum used for this study was collected from all herd females that calved before and during the trial and tested for quality using a colostrometer. Colostrum with specific gravity greater than $60 \mathrm{mg}$ of Ig per milliliter was used to create pooled lots. Lots of pooled colostrum ( $\mathrm{n}=$ 6 ) were frozen at $-20^{\circ} \mathrm{C}$ until feeding, at which time

Table 1. List of sires used in heterospermic semen combinations and the resulting number of progeny for each breed group

\begin{tabular}{llllll}
\hline & & \multicolumn{4}{c}{$\begin{array}{c}\text { No. of progeny } \\
\text { for each sire }\end{array}$} \\
\cline { 3 - 6 } $\begin{array}{l}\text { Breed and } \\
\text { designation }\end{array}$ & $\begin{array}{l}\text { Sire short } \\
\text { name }^{1}\end{array}$ & HH & HJ & JH & JJ \\
\hline Holstein & & & & & \\
H1 & Jasper & 9 & 3 & 0 & 0 \\
H2 & Cooper & 4 & 6 & 0 & 0 \\
H3 & Breton & 1 & 2 & 0 & 0 \\
H4 & Dane & 14 & 4 & 0 & 0 \\
Jersey & Freedom & 0 & 0 & 6 & 4 \\
J1 & Paramount & 0 & 0 & 1 & 0 \\
J2 & Parade & 0 & 0 & 3 & 1 \\
J3 & Elevation & 0 & 0 & 5 & 5 \\
J4 & alenyyyyy
\end{tabular}

\footnotetext{
${ }^{1}$ As given in Olson et al. (2009; Table 4).

${ }^{2} \mathrm{HH}=$ purebred Holstein; HJ $=$ Holstein $\times$ Jersey; JH $=$ Jersey $\times$ Holstein; JJ = purebred Jersey.
}

colostrum was warmed to at least $26.7^{\circ} \mathrm{C}$. Twelve hours later, a second feeding of colostrum was again given at $5 \%$ of rounded birth BW. Because individual calves were fed from pooled lots of colostrum without regard to breed of contributing female, the effect of quality of colostrum on the calf performance traits measured did not reflect the maternal genetic differences of Holstein and Jersey dams.

Beginning at $24 \mathrm{~h}$ of age, calves were moved to individual hutches and fed whole milk at $5 \%$ of rounded BW twice daily. Calves leaving greater than $0.47 \mathrm{~L}$ of colostrum or milk were fed via an esophageal feeder. Water and a starter ration were provided beginning at $3 \mathrm{~d}$ of age. Calves were weighed weekly, and the amount of milk fed daily was adjusted to $10 \%$ of calf rounded BW through 3 wk of age. Calf weaning occurred once intake of starter ration was equal to or greater than $1 \%$ of BW for $3 \mathrm{~d}$ consecutively, and days to weaning (DWN) was recorded as the age of the calf in days when this occurred.

Fecal scores were based on the method of Larson et al. (1977) and obtained daily through 6 wk to determine general level of health. Scores were ranked on a 1-to-4 scale with normal receiving a score of 1 and severe scouring a 4 . When fecal material was not present on a given day, an average was taken of the preceding and following days. Calves with fecal scores of 3 were fed electrolytes once daily $(1.9 \mathrm{~L})$, whereas calves with fecal scores of 4 were fed electrolytes twice daily (Merrick's Inc., Middleton, WI). Normal milk feeding continued during electrolyte supplementation.

\section{Sample Collection and Analysis}

Weekly BW $(\mathrm{kg})$, milk intake $(\mathrm{kg})$, and grain intake $(\mathrm{kg})$ were measured through 8 wk. Dry matter was calculated as $13 \%$ of milk intake and $89 \%$ of grain intake. Growth measures BW gain to 42 and 56 d (G42 and G56, respectively), weekly DMI and feed efficiency (FE) were calculated. Feed efficiency was defined as weekly BW gain divided by weekly DMI. Hip heights $(\mathrm{cm})$ were obtained within $48 \mathrm{~h}$ of birth and again at 6 wk of age.

\section{Statistical Analysis}

Data were analyzed as a randomized incomplete splitplot design (Littell et al., 1996). All analyses were conducted using the PROC GLM or MIXED procedures in SAS (v. 9.0, SAS Institute Inc., Cary, NC). Dependent variables were analyzed using PROC MIXED when repeated measures for a response variable were present (e.g., BW, DMI, FE, and hip height). For mixed models, calf represented the random effect and day was 
Table 2. Coefficients used to estimate genetic effects

\begin{tabular}{lcccc}
\hline & \multicolumn{4}{c}{ Genetic group $^{1}$} \\
\cline { 2 - 5 } Genetic effect & HH & HJ & JH & JJ \\
\hline Purebred & 1.0 & 0.5 & 0.5 & 0.0 \\
Heterosis & 0.0 & 1.0 & 1.0 & 0.0 \\
Maternal & 1.0 & 0.0 & 1.0 & 0.0 \\
\hline
\end{tabular}

${ }^{1} \mathrm{HH}=$ purebred Holstein; HJ $=$ Holstein $\times$ Jersey; JH $=$ Jersey $\times$ Holstein; JJ = purebred Jersey.

the repeated measure. Covariance structure was determined based on goodness-of-fit criteria: Akaike information criterion and Schwarz Bayesian criterion. The Kenward-Rogers degree-of-freedom method was used to determine appropriate degrees of freedom and mean squares to use in tests of significance of fixed effects in the analyses of variables with repeated measures.

For BW, DMI, FE, and hip height, the repeatedmeasures mixed model included as fixed effects sex (male or female) + parity of dam (first parity or second or greater) + colostrum lot (lots 1 to 6$)+$ day of age at sample collection (d 7, 14, 21, 28, 35, 42, 49, and 56) + purebred genetic effect + heterotic genetic effect + maternal genetic effect + the six 2-factor interactions among the 4 nongenetic fixed effects + covariates (dystocia score of dam's calving, beginning BW, DWN, and DMI; as appropriate).

For G42, G56, and DWN, the model included as fixed effects sex + parity of dam + colostrum lot + purebred genetic effect + heterotic genetic effect + maternal genetic effect + the three 2 -factor interactions among the nongenetic fixed effects + covariates (dystocia score of dam's calving, beginning BW, DWN and DMI; as appropriate).

Season was also recorded but not included in the model as a result of confounding with genetic groups and pooled colostrum lots. Dystocia score of the calving; DMI; DWN, beginning BW, or both were included as covariates in appropriate models but were removed from the model if nonsignificant $(P>0.10)$. All 2-way interactions between fixed effects were tested and removed from the model when nonsignificant $(P>0.10)$.

Coefficients for the genetic effects are presented in Table 2. Coefficients represent the percentage of Holstein genes in the calf (purebred genetic effect), percentage of Holstein genes in the dam of the calves (maternal genetic effect), and percentage of expected heterosis in the calf (heterotic genetic effect). Because there were only 2 purebred genetic groups with $0 \%$ expected heterosis and the 2 reciprocal $\mathrm{F}_{1}$ genetic groups each expressing $100 \%$ heterosis, the heterotic effect measured the difference between the average performance of the crossbreds and purebreds. The purebred genetic effect reflects the joint effect of additive and maternal genetic effect differences between purebred Holsteins and purebred Jerseys. Differences for means and genetic effects were considered significant at $P<$ 0.05 unless otherwise noted.

\section{RESULTS AND DISCUSSION}

\section{BW}

Purebred Holstein calves were $23.4 \mathrm{~kg}$ heavier on average than purebred Jersey calves from birth to 8 wk of age as a result of large purebred genetic effects (Table 3), an advantage also evidenced for Holstein birth weight in other designed crossbreeding experiments (Olson et al., 2009; Dhakal et al., 2013). The continued influence of Holstein genetics is reflected in comparisons using older purebred and crossbred calves (Hollon et al., 1972; Batra and Touchberry, 1974; Lee et al., 1988; Bjelland et al., 2011). Male calf BW increased more rapidly compared with female calves $(P<0.05)$, with an average BW gain of $33.3 \mathrm{~kg}$ compared with $31.0 \mathrm{~kg}$ for females by $8 \mathrm{wk}$ of age (Table 4, Figure 1 ).

Overall colostrum lot differences did not affect BW; however, the interaction of colostrum lot and day was significant $(P<0.01)$. Calves fed lots 1 and 6 had an $11 \%$ greater BW gain at $56 \mathrm{~d}$ (lots 1 and 6 average $\mathrm{G} 56=30.9 \mathrm{~kg}$ ) compared with calves that received other colostrum lots (lots $2-5$ average G56 = $24.6 \mathrm{~kg}$ ). This may be indicative of a season effect rather than a differential colostrum effect. Calves born in the summer have shown lower DMI and ADG (Place et al., 1998). Consequently, BW may be negatively related to summer season. In this experiment, colostrum lots 1 and 6 were fed during the winter season, whereas the remaining lots were primarily fed during the summer season. The partial confounding of colostrum lot with season of birth may be responsible for differences in BW rather than colostrum lots. Other dependent variables had a significant $(P<0.05)$ colostrum lot-by-day interaction, likely representing a season effect rather than colostrum-quality effect.

\section{$D M I$}

Purebred and heterotic genetic effects influenced DMI of calves. Calves with Holstein genetics had greater DMI compared with purebred Jersey calves, and crossbred calves consumed $0.74 \mathrm{~kg}$ more DM than the average of the purebreds $(P<0.05$; Table 3$)$. An interaction for DMI between parity of dam and day reveals DMI was less than $5 \mathrm{~kg}$ for $21 \%$ of calves from multiparous dams compared with only $10 \%$ of calves from primiparous dams at $49 \mathrm{~d}$ of age (Figure 2). Fecal scores did not indicate any sickness among the calves during this 
Table 3. Genetic-effect estimate results of growth and performance traits for Holstein $\times$ Holstein $(\mathrm{HH})$, Holstein $\times$ Jersey $($ HJ), Jersey $\times$ Holstein $(\mathrm{JH})$, and Jersey $\times$ Jersey $(\mathrm{JJ})$ calves from birth to 8 wk of age

\begin{tabular}{|c|c|c|c|c|c|c|c|}
\hline \multirow{2}{*}{ Genetic effect } & \multicolumn{7}{|c|}{ Genetic-effect estimate } \\
\hline & \multicolumn{4}{|c|}{ Repeated measure } & \multicolumn{3}{|c|}{ Single measure } \\
\hline${\text { Purebred (HH-JJ) }{ }^{1}}^{1}$ & $23.45^{* *}$ & $3.04^{* *}$ & -0.02 & $4.37^{*}$ & $5.48^{* *}$ & $10.32^{* *}$ & -5.09 \\
\hline Heterotic $^{2}$ & 1.25 & $0.74^{*}$ & -0.08 & $1.44^{*}$ & -0.02 & -0.72 & $-4.51 \dagger$ \\
\hline
\end{tabular}

${ }^{1}$ Positive estimates indicate $\mathrm{HH}>\mathrm{JJ}$.

${ }^{2}$ Positive estimates indicate crossbreds $>$ purebreds.

${ }^{3}$ Negative estimates indicate $\mathrm{xJ}>\mathrm{xH}$.

${ }^{* *} P<0.01 ;{ }^{*} P<0.05 ; \nmid P<0.1$.

time period. Overall, calves born to multiparous dams consumed $6.2 \mathrm{~kg}$ of DMI, whereas calves of primiparous dams averaged $6.4 \mathrm{~kg}$ of DMI, indicating that although the rate of DMI differed over time for calves, by the end of the study, calves were consuming similar amounts of $\mathrm{DM}$, regardless of the parity of the dam.

\section{Hip Height}

The skeletal measurement examined in this trial was calf hip height at birth and at $42 \mathrm{~d}$ of age, with heavier birth weights positively associated with greater hip heights (Table 4). Similar to other growth traits, purebred genetic effects strongly influenced hip height (Table 3). Heterotic effects were significant $(P<0.05)$, and crossbred calves were $1.20 \mathrm{~cm}$ taller than the purebred calves. Into maturity, crossbred calves continue to exhibit similar structural measurements, including hip height, although this is not the case for every breed crossed with pure Holsteins (Hazel et al., 2014). Despite crossbred calves being taller and having greater

Table 4. $F$-values from mixed-model analyses of growth and performance parameters for Holstein $\times$ Holstein $(\mathrm{HH})$, Holstein $\times$ Jersey $(\mathrm{HJ})$, Jersey $\times$ Holstein $(\mathrm{JH})$, and Jersey $\times$ Jersey $(\mathrm{JJ})$ calves from birth to 8 wk of age

\begin{tabular}{|c|c|c|c|c|c|c|c|c|}
\hline Source of variation & df & \multicolumn{7}{|c|}{$F$-value } \\
\hline \multicolumn{9}{|l|}{ Covariates $^{1}$} \\
\hline Dystocia & 1 & $\mathrm{NA}^{2}$ & NA & $9.25^{* *}$ & NA & NA & NA & NA \\
\hline DMI & 1 & $78.34^{* *}$ & - & NA & NA & $36.02^{* *}$ & $23.45^{* *}$ & NA \\
\hline \multicolumn{9}{|l|}{ Genetic effects } \\
\hline Purebred effects & 1 & $70.13^{* *}$ & $16.26^{* *}$ & 0.00 & $5.74^{*}$ & $13.75^{* *}$ & $20.17^{* *}$ & 1.14 \\
\hline Heterotic effects & 1 & 0.80 & $3.86^{*}$ & 0.20 & $5.37^{*}$ & 0.00 & 0.44 & $3.56 \dagger$ \\
\hline Maternal effects & 1 & 1.13 & 2.22 & 0.18 & 0.63 & 1.35 & 2.95 & 1.45 \\
\hline \multicolumn{9}{|l|}{ Fixed effect } \\
\hline Sex & 1 & $6.69^{*}$ & 2.16 & 0.00 & 0.04 & $3.53 \dagger$ & $5.29 *$ & 0.70 \\
\hline Sex by lot & 5 & $\mathrm{NA}$ & NA & NA & NA & NA & NA & $\mathrm{NA}$ \\
\hline Sex by day & 8 & $2.85^{* *}$ & NA & NA & NA & NA & NA & NA \\
\hline Parity by day & 8 & NA & $4.71^{* *}$ & NA & NA & NA & $\mathrm{NA}$ & $\mathrm{NA}$ \\
\hline Parity by lot & 6 & NA & NA & NA & NA & NA & NA & NA \\
\hline Lot by day & 40 & $2.37^{* *}$ & $3.54^{* *}$ & NA & $2.35 \dagger$ & NA & NA & NA \\
\hline
\end{tabular}

${ }^{1}$ Covariates were included only in applicable models. They were removed if $P>0.10$.

${ }^{2}$ Nonsignificant covariates $(P>0.10)$ and 2 -way interactions $(P>0.10)$ were removed from final model to avoid overspecification. Variables that were not applicable to the model were not included; see Methods section for statistical models.

${ }^{* *} P<0.01 ;{ }^{*} P<0.05 ; \dagger P<0.10$. 


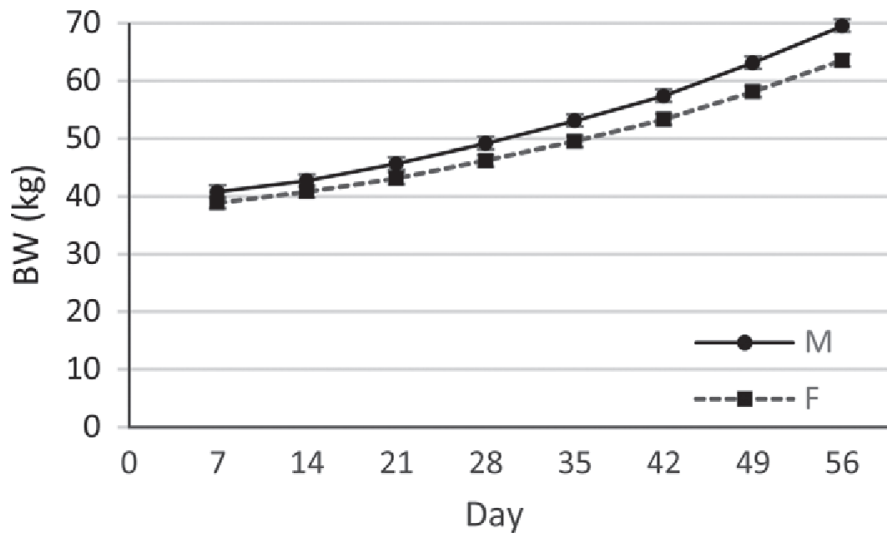

Figure 1. Body weight $( \pm$ SEM) difference of male $(\mathrm{M})$ and female (F) calves from 7 to $56 \mathrm{~d}$.

DMI relative to their purebred counterparts, these differences did not translate into improved feed efficiency.

\section{Feed Efficiency}

Genetic effects for FE were not significant (Table 3) in agreement with previous findings of no differences between purebred and crossbred cows (Ellersieck et al., 1977; Lee et al., 1988; Quigley and Wolfe, 2003; Heins et al., 2008). In contrast, Holstein male calves had a greater FE when compared with Jersey male calves from birth to $29 \mathrm{~d}$ of age (Jones et al., 2004), and additive effects on feed efficiency have been reported for postcalfhood beef cattle (Ellersieck et al., 1977). Feed efficiency doubled at $7 \mathrm{wk}$ of age for calves on this study, concurrent with a large increase in BW. This time period may be a point of inflection in the growth curve of the calves. It is possible that restricted milk feeding (at 10\% of BW) obscured differences in feeding efficiencies. Khan et al. (2007) reported that calves fed greater volumes of milk had greater feed efficiencies than those on a restricted milk diet. Increased dystocia score was associated with increased $\mathrm{FE}(P<0.01$; Table 4) for unknown reasons.

\section{BW Gain to 42 and $56 d$}

Dry matter intake and DWN strongly predicted G42 and G56 (Table 4). Furthermore, a strong purebred genetic effect $(P<0.01)$ favoring the Holstein breed was present for both G42 and G56 (Table 3). Calves with Holstein genetics gained $5.5 \mathrm{~kg}$ more than purebred Jersey calves at $42 \mathrm{~d}$ and $10.3 \mathrm{~kg}$ more at $56 \mathrm{~d}$. Greater BW gain of older Holstein calves compared with purebred Jersey calves is well documented (Shreffler and Touchberry, 1959; Bereskin and Touchberry, 1967). In general, male calves tended to have greater gains

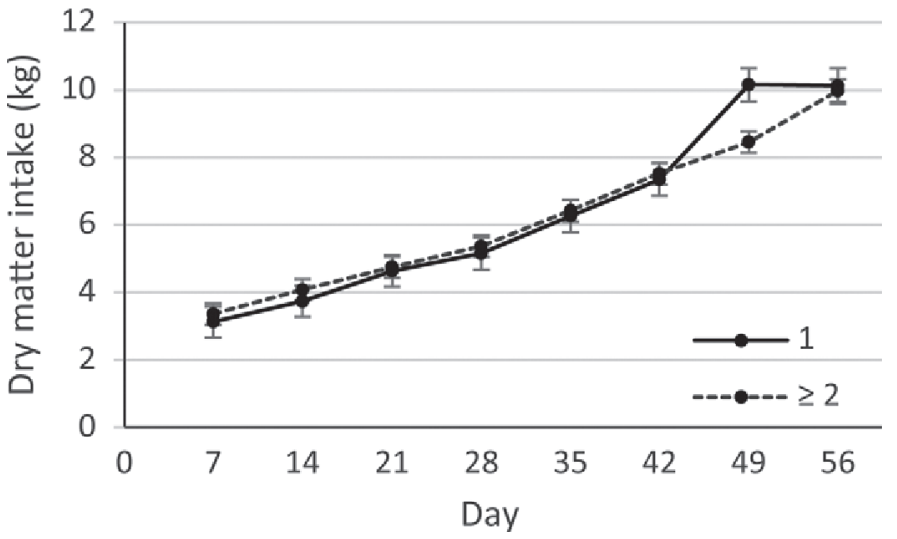

Figure 2. Dry matter intake $( \pm \mathrm{SEM})$ from 7 to $56 \mathrm{~d}$ of age for calves from primiparous (1) and multiparous $(\geq 2)$ dams.

than female calves at $42 \mathrm{~d}(P=0.07)$ and significantly greater G56 $(P<0.05)$. However, for G56, male calves born to multiparous dams did not have greater $\mathrm{BW}$ gain, though the reason for this is not clear (Figure 3). Higher ADG during the preweaning phase is also associated with greater milk yields during first lactation (Soberon et al., 2011).

\section{Days to Weaning}

Heterosis approached significance $(P=0.06)$ because crossbred calves tended to wean $4.5 \mathrm{~d}$ earlier than the average of the purebreds. Earlier weaning decreases feed and labor costs (Davis and Drackley, 1998; Kehoe et al., 2007) and age at first calving (Cady and Smith, 1996).

\section{5}

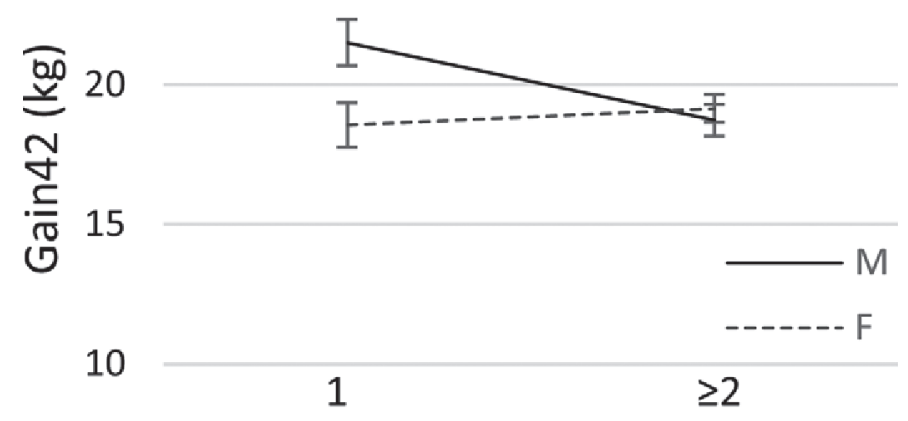

\section{Parity of dam}

Figure 3. Body weight gain ( \pm SEM) at $42 \mathrm{~d}$ of age (Gain42) for male $(\mathrm{M})$ and female $(\mathrm{F})$ calves. 


\section{CONCLUSIONS}

Purebred genetic effects significantly influenced all of the growth traits examined in this study with the exception of FE. Taken together with heterotic effects favoring increased DMI and hip height as well as a tendency to decrease DWN, calves with Holstein genetics, either purebred or crossbred, will exhibit strong performance through later calfhood and maturity. Maternal effects, defined here as the percentage of Holstein genetics in the dam of the calf, did not appear to play a major role in the traits examined.

\section{REFERENCES}

Batra, T., and R. Touchberry. 1974. Weights and body measurements of purebred Holstein and Guernsey females and their crossbreds. J. Dairy Sci. 57:842-848.

Bereskin, B., and R. W. Touchberry. 1967. Crossbreeding dairy cattle. IV. Effects of breed group, lactation production, and pregnancy on body growth. Generation 1. J. Dairy Sci. 50:876-883.

Bjelland, D. W., K. A. Weigel, P. C. Hoffman, N. M. Esser, W. K. Coblentz, and T. J. Halbach. 2011. Production, reproduction, health, and growth traits in backcross Holstein $\times$ Jersey cows and their Holstein contemporaries. J. Dairy Sci. 94:5194-5203.

Buckley, F., N. Lopez-Villalobos, and B. J. Heins. 2014. Crossbreeding: Implications for dairy cow fertility and survival. Animal 8(Suppl. 1):122-133.

Cady, R. A., and T. R. Smith. 1996. Economics of heifer raising programs. Pages 7-24 in Proc. NRAES Conf. Calves, Heifers, Dairy Profit.: Facil., Nutr., Health., Harrisburg, PA.NRAES-74, Ithaca, NY.

Davis, C., and J. Drackley. 1998. Starter feed: Importance, composition, and intake. Pages 283-306 in The Development, Nutrition and Management of the Young Calf. Iowa State Univ. Press, Ames.

Dhakal, K., C. Maltecca, J. P. Cassady, G. Baloche, C. M. Williams, and S. P. Washburn. 2013. Calf birth weight, gestation length, calving ease, and neonatal calf mortality in Holstein, Jersey, and crossbred cows in a pasture system. J. Dairy Sci. 96:690-698.

Ellersieck, M., J. Lasley, W. Sibbit, and L. Langford. 1977. Heterosis in feed efficiency of beef steers. J. Anim. Sci. 45:703-707.

Hazel, A. R., B. J. Heins, A. J. Seykora, and L. B. Hansen. 2014 Production, fertility, survival, and body measurements of Montbéliarde-sired crossbreds compared with pure Holsteins during their first 5 lactations. J. Dairy Sci. 97:2512-2525.

Heinrichs, A. J., and L. Swartz. 1990. Management of Dairy Heifers. Extension Circular. Pennsylvania State Univ., Agric. Ext. Serv., University Park.

Heins, B., L. Hansen, A. Seykora, A. Hazel, D. Johnson, and J. Linn. 2008. Crossbreds of Jersey $\times$ Holstein compared with pure Holsteins for body weight, body condition score, dry matter intake, and feed efficiency during the first one hundred fifty days of first lactation. J. Dairy Sci. 91:3716-3722.

Hollon, B., C. Branton, and K. Koonce. 1972. Performance of Holstein and crossbred dairy cattle in Louisiana. II. Growth rate through first lactation. J. Dairy Sci. 55:113-122.

Jones, C. M., R. E. James, J. D. Quigley 3rd, and M. L. McGilliard. 2004. Influence of pooled colostrum or colostrum replacement on IgG and evaluation of animal plasma in milk replacer. J. Dairy Sci. 87:1806-1814
Kasimanickam, R., R. Nebel, I. Peeler, W. Silvia, K. Wolf, A. McAllister, and B. Cassell. 2006. Breed differences in competitive indices of Holstein and Jersey bulls and their association with sperm DNA fragmentation index and plasma membrane integrity. Theriogenology 66:1307-1315.

Kehoe, S. I., C. D. Dechow, and A. J. Heinrichs. 2007. Effects of weaning age and milk feeding frequency on dairy calf growth, health and rumen parameters. Livest. Sci. 110:267-272.

Khan, M. A., H. J. Lee, W. S. Lee, H. S. Kim, S. B. Kim, K. S. Ki, J. K. Ha, H. G. Lee, and Y. J. Choi. 2007. Pre- and postweaning performance of Holstein female calves fed milk through step-down and conventional methods. J. Dairy Sci. 90:876-885.

Larson, L., F. Owen, J. Albright, R. Appleman, R. Lamb, and L. Muller. 1977. Guidelines toward more uniformity in measuring and reporting calf experimental data. J. Dairy Sci. 60:989-991.

Lee, A., C. Lin, A. McAllister, K. Winter, G. Roy, J. Vesely, J. Wauthy, T. Batra, and A. Atwal. 1988. Growth and feed efficiency of pureline and crossline dairy heifers. J. Dairy Sci. 71:1000-1010.

Lesmeister, K., D. Kellogg, A. Brown Jr., Z. Johnson, and A. Lane. 2000. Effects of crossbreeding and season of calving on production of milk fat and protein of primiparous dairy cows. J. Dairy Sci 83(Suppl. 1):52.

Littell, R. C., G. A. Milliken, W. W. Stroup, and R. D. Wolfinger 1996. SAS System for Mixed Models. SAS Institute, Cary, NC.

Lopez-Villalobos, N., D. J. Garrick, C. W. Holmes, H. T. Blair, and R. J. Spelman. 2000. Profitabilities of some mating systems for dairy herds in New Zealand. J. Dairy Sci. 83:144-153.

McAllister, A., A. Lee, T. Batra, C. Lin, G. Roy, J. Vesely, J. Wauthy, and K. Winter. 1994. The influence of additive and nonadditive gene action on lifetime yields and profitability of dairy cattle. J. Dairy Sci. 77:2400-2414.

McDowell, R. E. 1982. Crossbreeding as a system of mating for dairy production. South. Coop. Ser. Bull. No. 259. Louisiana Agric. Exp. Stn., Baton Rouge.

Olson, K., B. Cassell, A. McAllister, and S. Washburn. 2009. Dystocia, stillbirth, gestation length, and birth weight in Holstein, Jersey, and reciprocal crosses from a planned experiment. J. Dairy Sci. 92:6167-6175.

Place, N. T., A. J. Heinrichs, and H. N. Erb. 1998. The effects of disease, management, and nutrition on average daily gain of dairy heifers from birth to four months. J. Dairy Sci. 81:1004-1009.

Quigley, J. D., and T. Wolfe. 2003. Effects of spray-dried animal plasma in calf milk replacer on health and growth of dairy calves. J. Dairy Sci. 86:586-592.

Shreffler, D. C., and R. Touchberry. 1959. Effects of crossbreeding on rate of growth in dairy cattle. J. Dairy Sci. 42:607-620.

Soberon, F., E. Raffrenato, R. Everett, and M. Van Amburgh. 2011. Early Life Management and Long-Term Productivity of Dairy Calves. Dept. Anim. Sci. New York State Coll. Agric. Life Sci. Cornell Univ., Ithaca, NY.

Sørensen, M. K., E. Norberg, J. Pedersen, and L. Christensen. 2008 Invited review: Crossbreeding in dairy cattle: A Danish perspective. J. Dairy Sci. 91:4116-4128.

Touchberry, R. W. 1992. Crossbreeding effects in dairy cattle: The Illinois experiment, 1949 to 1969. J. Dairy Sci. 75:640-667.

Virtala, A. M. K., G. Mechor, Y. Gröhn, and H. Erb. 1996. The effect of calfhood diseases on growth of female dairy calves during the first 3 months of life in New York State. J. Dairy Sci 79:1040-1049.

Weigel, K. A., and K. A. Barlass. 2003. Results of a producer survey regarding crossbreeding on US dairy farms. J. Dairy Sci. $86: 4148-4154$ 